\title{
Articulations of the Real: from Lacan to Badiou
}

\author{
LUCY BELL
}

\begin{abstract}
:
This article gives a comparative analysis of the way in which Lacanian psychoanalysis and Alain Badiou's mathematical ontology understand the category of the real, respectively, as the foundation of individual subjectivity or the name of being-as-being. A number of shifts in focus arise from the fundamental difference in the location of the void: from the individual act to the collective event; from death drive to immortal truth; from subjective destitution and cathartic purification to transformative interventions and constitutive thought. These shifts are exemplified, elaborated and analysed through a close reading of the thinkers' respective commentaries on Sophocles' Antigone. Foregrounding what is philosophically at stake in these differences, the article defends Badiou against Lacanian critics (most notably Slavoj Žižek and Eleanor Kaufman) by examining the ethical and political force of his innovation.
\end{abstract}

Keywords: Badiou, Lacan, psychoanalysis, ontology, void, the real, truth, subtraction

The Location of the Void

Alain Badiou avowedly owes much of his radical philosophy to his 'master', Jacques Lacan. ${ }^{1}$ It is puzzling, therefore, that psychoanalytical critics have painstakingly sought to defend and preserve Jacques Lacan's thought against, rather than through, that of Badiou. In fact, by bringing these two anti-humanists together under their shared articulations of the irreducible, inassimilable real, it is possible to see how Badiou provides his contemporaries with a means of expanding and extending, rather than contracting and restricting, Lacanian theory.

Paragraph 34.1 (2011): 105-120

DOI: $10.3366 /$ para.2011.0008

(C) Edinburgh University Press

www.eupjournals.com/para 
Critics have often pinpointed the limitations of Badiou's philosophy. Slavoj Žižek, for example, argues that 'what remains beyond Badiou's reach is [the] "domain beyond the good", in which a human being encounters the death-drive at the utmost limit of human experience, and pays the price by undergoing a radical "subjective destitution", by being reduced to an excremental remainder'. ${ }^{2}$ For Žižek, the Lacanian subject's 'limit-experience' sets him apart from the Badiousian subject (TS, 161). Likewise, Eleanor Kaufman asserts that it is 'the proximity to the extreme that for Lacan marks the space of the ethical, a perhaps paradoxical and certainly liminal space where the living and the human encounter their limits'. Badiou's thought, these critics suggest, is simply not as revolutionary as that of Lacan; his ethics are severed from the 'extreme'. Yet at the heart of both systems of thought lies a singular, fragile encounter with the real, the inhuman 'domain beyond the good' which is reformulated by Badiou as inconsistent multiplicity, or being-as-being. Badiou's project is inseparable from the underlying desire to take thought to its very boundaries, to push philosophy to the limits of human experience: for him, genuine thought can only occur through the eruption of a particular, indiscernible truth into a specific situation, where 'truth' is to be understood as a gradual, subjective process that disrupts consensual knowledge. My aim, therefore, is to challenge those views that set Lacan apart from, and above, Badiou, by re-framing the debate over the category of the real in order to see these 'limits' and 'extremes' from a different angle.

Kaufman and Žižek justly pinpoint an essential difference between the Lacanian act and the Badiousian event: such differences exist. In the former, the encounter is inextricable from mortality, the death-drive and, to use Lacan's own words, 'destruction beyond putrefaction'. ${ }^{4}$ In the latter, the event is linked with infinity, immortality and subjective constitution. Yet this is due to a deeper, more fundamental, difference between the two theories, one that concerns the location of that which Lacan and Badiou term the void.

In order to understand the nature of the Badiousian void, one must first grapple with the different layers in Badiou's ontology. Being, or being-as-being, is for Badiou an 'irreducible multiplicity', a pure, inconsistent, unstructured multitude of elements. These existent elements form a 'situation': a basic structure, a particular set of multiples, or a 'consistent presented multiplicity'. 6 When these elements are collected together under a shared term (like Victorian society, modern art or capitalism), they are, in Badiou's terms, 'counted 
as One' $(B E, 24)$. From this count-as-One arises a representation of the presented multiplicity, a metastructure which Badiou terms the 'state of the situation', referring at once to political state and general status quo. Viewed from the perspective of the state of the situation, the inconsistent multitude - pre-symbolic being, or being-as-being appears as nothing.

Herein emerges the principal difference between Lacan and Badiou: whereas for Lacan, the void inhabits and founds the desiring subject, for Badiou, it constitutes being-as-being. Although Lacan's act and Badiou's event both involve a subject, the Badiousian subject is dialectically intertwined with the truth: the truth results from a process driven by the fidelity of the subject; yet the subject is not a given structure that pre-exists the event, but rather, as Badiou explains, 'induced' by the truth-process itself. ${ }^{7}$ It is Badiou's relocation of the void that causes a dramatic shift in theoretical focus, from the private, mortal, (self-)destructive subject to the universal, infinite, constitutive truth. Examining the two thinkers from a topological angle will allow us to see the merit of Badiou's philosophy, which rearticulates Lacan's ontological structures as truth-processes.

The intersections and divergences between Lacan and Badiou not only furnish a deeper insight into both their systems of thought into the limitations, but also the productive potential, of Lacanian psychoanalysis, and its impact on Badiou's work. It also sheds light on a broader encounter between psychoanalysis and philosophy, most notably in the Freudo-Marxist thought that encompasses thinkers from Wilhelm Reich and Otto Fenichel to Herbert Marcuse and Slavoj Žižek himself. Moreover, the discrepancies in their treatment of the real foregrounds the great political stakes that are at play in the debate over this philosophical category, a debate that encompasses the work of such thinkers as Fredric Jameson, Ernesto Laclau, Chantal Mouffe and Bruno Bosteels. Indeed, the debate over this category, of how it can be thought or articulated within our existing knowledge, may well be conceived as the crux of all modern philosophy.

\section{Shared Encounters: Lacan's Act and Badiou's Event}

If the void of the real is the most basic element shared by Lacan and Badiou, it is crucial to examine the excess that correlates with it. The death of God, figured in Badiou's thought by the axiom that 'the One is not' $(B E, 90)$, means that 'the only halting-point 
is the void'. 8 In Lacan's work, this limit is represented by the big Other - understood as absolute otherness, and thus from a certain perspective, God - which is crucially barred, lacking, non-existent. The reverse side of this lack is for both theorists an excess. The Badiousian state of the situation, like the Lacanian symbolic order, constitutes a necessary defence mechanism that serves as a floodgate against the perils of the void (or in political terms, against anarchy). In Badiou's terms, this means that, although the One is not, 'there is Oneness' $(B E, 24)$. Yet the meta-structural protection it provides also poses a threat to the structure it represents, since it is precisely the excess of the state over the elements that it seeks to organize that opens up a crack in the symbolic wall-paper and hence leaves room for disruption.

For Lacan, the relationship between void and excess is that between the split subject and the excessive law, the kingdom of language and culture superimposed on that of nature and unbridled sexuality. Badiou formulates it mathematically, using Cantor's set theory. First, every set includes a non-decomposable term, a foundational element, to which nothing belongs: the empty set, the 'halting-point', the 'ur-element', such as biochemical structures in the set of living things or a single note within the situation of a piece of music. ' Second, there is a necessary excess of subsets over elements, because it is formally impossible (...) for everything which is included (every subset) to belong to the situation' (BE, 97). Examples of such excess include the figure of the Jew within the anti-Semitic situation and that of the unemployed within the capitalist situation.

In other words, the constitutive void-set in the situation correlates with the exclusion of certain elements from the state of the situation, which results in the excess of representation over presentation, of the state over the situation, and of inclusion over belonging, an excess which for both theorists constitutes the impasse of being. ${ }^{10}$ This mathematical ontology corresponds to the terms used by Žižek to uphold Lacan's theory: the 'halting-point' of the void is Žižek's 'limitexperience', and the correlative excess is his 'symptom'. It is the possibility of rupture through an event opened up by this excess that brings Badiou closest to his 'master Lacan'.

In Theory of the Subject, perhaps the most Lacanian of his writings, Badiou explores the correlation between lack and excess through the relationship between Antigone and Creon in Sophocles' Antigone. Bruno Bosteels sums up the argument in the following succinct terms: 
Not only does Antigone's anxiety-ridden decision not to give up on her desire seem to provoke in return the destructive rage inherent in the law, that is, the element of violent nonlaw parading in the guise of the law of the city-state: but also her rebellion is $(\ldots)$ the reaction to the excessive form of Creon's law. ${ }^{11}$

The nonlaw is the Janus face of the law, the void-set that is simultaneously excluded from, and omnipresent within, the state of the situation. While Antigone's anxiety is a manifestation of the void, the infinity of the real which is excluded from the finite situation, Creon's rage represents the inherent excess of the law, the huge excrescence of the state (imposed by that very law) over the situation. The siblings are therefore mutually dependent.

The Badiousian subject of the event is therefore a combination of Antigone and Creon, located simultaneously at the level of lack/excess, void/surplus. The two thinkers' readings of Antigone, used by Kaufman as an example to raise Lacan above his successor, can therefore be seen rather to draw them closer together. What Lacan refers to as 'the violent illumination, the glow of beauty, [which] coincides with the moment of transgression or of realization of Antigone's Ate' (S VII, 346), is arguably closer to Badiou's event than in Kaufman's account: it is precisely a manifestation of the real that underpins and founds the state of the situation. Like the Lacanian Ate, the event can be described as 'the limit that human life can only briefly cross' ( $S$ VII, 262-3). Moreover, it retains the elements that characterize the act in Lacan's own terms: violence (since an event always constitutes a radical rupture from the current state of the situation); transgression (entailed by that rupture); real-ization (of the subject, and the truth he embodies, through fidelity). Although for Badiou, the trace of the infinite is not a passive, futile, aesthetic manifestation of beauty, but rather the active, interventionist, political decision of the event, his theory inherits the crucial notion that the real, albeit inaccessible to direct experience, can have a radical effect on the situation.

This is why Kaufman's summary of Lacan's Seminar XI is strikingly close to a description of the truth-event:

What is articulated painstakingly throughout the desire seminar is the way in which something phantasmic appears out of a space that is neither entirely conscious nor unconscious. It appears from material that is present yet not registered as such, often involving a relationship to or a prescience of death. $(W F, 140)$ 


\section{Paragraph}

In Badiousian terms, the phantasmic element is an event; its site is the edge of the void, the liminal space between representation and presentation; it hovers between immanence and transcendence, composed on the one hand entirely by the elements of its site, yet on the other hand constituting a brand-new configuration that cannot be thought within the situation. The only aspect of this apparition that is not carried forth by Badiou is its relationship with death, one that, as we shall see, he replaces with an inextricable connection to immortality.

Žižek's claim that Badiou's event fails to reach 'beyond the domain of the good' might therefore be contested. Indeed, Badiou rejects the Kantian conflation of ethics, morality and practical reason, to which the contemporary 'return to ethics' owes much of its impetus $(E, 2)$. Going beyond the good, for him, means breaking away from the consensual social good linked to happiness, pleasure and health, into a territory of singular, contingent, rare truth-processes: the domain of the Good. ${ }^{12}$ This echoes Lacan's insistence that 'a radical repudiation of a certain ideal of the good is necessary' (S VII, 284), where the good designates passive conformity to the social and moral norm. It follows that Lacanian beauty is 'closer to evil than to good' (S VII, 268): the truth that beauty disguises is closer to the exceptional rebellion of evil than to the accepted norm of good. For Badiou, likewise, 'it is absolutely essential that Evil be a possible dimension of truths' $(E, 60-1)$. Yet whereas Lacan privileges the evil manifested in beauty over the consensual good, Badiou's truth-process implies the supremacy of Good over Evil. Since the truth-process is defined by the emergence of the exceptional Good from the social good, Evil is merely an effect of the Good, its betrayal, simulacrum, or forcing (E, 71).

Kaufman's assertion that Badiou fails to account for the Lacanian 'confrontation with an inhuman limit' (WF, 136) might also be re-evaluated. From a Badiousian perspective, the event is of the order of infinity, immortality and inhumanity, rather than finitude, mortality and humanity. Badiou himself insists on this point:

In crucial experiences, such as love, artistic creation, scientific discoveries, political struggle, we must exceed the limits of our vital and social determinations. We must encounter, within our own humanity, the obscure, violent, at the same time luminous and peaceful, element of inhumanity within the human element itself. ${ }^{13}$

Antigone's inhumanity encapsulates all of these qualities: her isolated drive to bury her brother is shrouded in obscurity; her transgression 
of Creon's law is violent and disruptive; her splendour is luminous (though certainly not peaceful). Moreover, she embodies inhumanity as the creative aspect of humanity, because her actions reveal that part of her nature that does not exist in the present but must become in the future: her desire. Badiou's elaboration of Lacan, however, means that desire is lifted from the realm of psychoanalysis, sexuality and individual subjectivity. His unique philosophical position stems from his rearticulation of Lacanian desire as the becoming of a universal truth.

\section{From Appearing Acts to Constitutive Events: Badiou against Lacan}

In spite of the similarities between act and event, Badiou's relocation of the void leads to the reconfiguration of this foundational moment of rupture. By regarding the void as the constitutive, irreducible element of being-as-being, rather than that of specific subjects, Badiou's transition from act to event implies other related shifts: from private to universal; from mortality to immortality; from the entrenchment in language to an indifference towards discourse.

First, the position of the void affects that of the subject in the two theories. Whereas psychoanalysis, in its original conception as a means of treating psychosis, is essentially subject-centred, Badiou's philosophy is truth-centred as well as subject-centred. Although the Badiousian truth relies upon a subjective intervention, this is not to say that it is private or personal. In Badiou's own terms, 'he who is a militant of truth identif[ies] himself (...) on the basis of the universal'. ${ }^{14}$ The universality of the Badiousian truth contrasts sharply with Lacan's deeply individualistic, private ethic: 'don't give way on your desire' ( $S$ VII, 304, my emphasis). Although these positions are brought closer together in Badiou's Ethics: An Essay on the Understanding of Evil, where Badiou upholds Lacan's motto, it remains that Badiou's subject must be faithful to an indiscernible truth that 'seizes' him $(E, 47)$. He is subject to truth as well as a subject of truth. In the case of Lacanian psychoanalysis, the desiring subject is the magnetic centre towards which everything is directed, and by which the world is engulfed. In the case of Badiousian philosophy, the subject of/to the truth-process is born from self-abandonment, perhaps even asceticism, as his individual identity is subsumed by the universal truth.

Second, the transition from the analytic act to the truth-event entails a movement from mortality to immortality. In both cases, the aim of 


\section{Paragraph}

the process lies in living with a 'piece of the real' and basing one's future existence around it. For Lacan, this is almost synonymous with identifying with one's symptom, living with death, coming to terms with one's own mortality. It is difficult to uncouple this symptom from the notion of original sin: it is deeply embedded within, albeit dissonant with, one's subjectivity; something foundational, originary, to which the human subject is shackled. In Badiou's thought, on the contrary, the void is no longer 'in you more than you', to use the final title of Lacan's famous Seminar XI ${ }^{15}$ but rather in being-as-being, that ontological domain from which subjectivity is subtracted in the fidelity to a truth. The movement from Lacan's ontology to Badiou's philosophy thus entails the evaporation of the notion of original sin and mortality. Living with a 'piece of the real' involves embracing one's subjective immortality due to the constitution of an infinite, universal truth.

The two theorists' interpretations of Sophocles' Antigone shed light on their differing positions. Antigone is the heroine of psychoanalysis because she assumes her human state of finitude, her position of limbo 'between two deaths' (S VII, 332-53). On the contrary, for Badiou, her transgression lies not in the acceptance, but in the defiance, of finitude through her fidelity to an infinite truth-procedure.

Third, in Lacanian theory, the act is inseparable from the speech act, which is the only means of accessing the truth of the subject's desire. There is consequently a direct relation between act, speech and truth: 'truth hollows its way into the real thanks to the dimension of speech'. ${ }^{16}$ In Badiou's philosophy, conversely, there is a distinct separation between event (the act), evental statement (the speech act) and truth (the subsequent process). If Antigone's act, from a Lacanian perspective, is essentially a linguistic act, this for Badiou is not the event itself, but the evental statement. ${ }^{17}$ The latter is not strictly speaking the event's name, but the mark it leaves in the situation. In Lacanian terms, the evental statement is therefore closer to beauty than to the act, since it is an effect, an implicative remainder of the real rather than an encounter with it. Badiou's truth per se, moreover, is separate from both the event that produces it and the statement that declares it: as Badiou says himself, his 'truth only exists insofar as it is indifferent to [language]'; truths are undecidable, indiscernible, unnameable and generic; they 'avoid the entire encyclopaedic grasp of the state' (BE, 433).

The gap between situation and event, knowledge and truth, is for many critics the greatest weakness of Badiou's thought, since 
the reliance on faith and conviction leads to possible obscurantism, mysticism and political delusion. Peter Osborne is right to question Badiou's work on this account, to be suspicious of an event that is 'literally "unnameable" within the language of the situation', ${ }^{18}$ within the field of knowledge. Yet the event's unnameable quality does not mean that, as Osborne maintains, it has no relation to the situation in which it occurs, that it is 'absolute novelty, a pure beginning' (25). As Badiou himself argues in an interview with Bosteels, the event is neither absolute novelty, since it is nothing else than the set of elements in its site', ${ }^{19}$ nor absolute purity, since its unfolding involves a forcing, a torsion that is characterized by complexity and impurity.

Similarly, Žižek is only partially justified in his suspicion that Badiou 'is unable to expand the encounter of the Real into a discourse' ${ }^{20}$ The term 'unable' betrays a rather one-sided view: this weakness, seen from a different angle, is also a strength; from a Badiousian perspective, it is Lacan who is unable to uncouple the encounter of the real from discourse. Because of Badiou's relocation of the void, the truth emerges from being-as-being, between the gaps in discourse, rather than out of the hysteric subject's speech act or evental statement. It is therefore beyond discourse. This is why Badiou's main criticism of Lacanian thought is its being 'overly soldered to language alone', its lack of the 'radical suspension of truth from the supplementation of beingin-situation [or subject-in-language, subject-as-language] by an event which is the separator of the void' (BE, 433-4). Against this reduction of truth to fiction, simulacrum and non-truth, Badiou posits the view of truth as exceptional supplement to the normal order of knowledge. In Lacanian terms, the event opens up and uncouples the suture-tobeing, the 'quilting point' that unites the signifier and the signified, ${ }^{21}$ and thus allows the subject to be born not from language, but from the rupture in language.

There is therefore another crucial difference between a Lacanian and Badiousian reading of Sophocles' tragedy. Lacan's Antigone can only subvert the system of the state from within its own language (or encyclopaedia, in Badiou's terms), though her verbal act cannot be fully assimilated by the state. She is located at - and indeed constituted by - the threshold of the symbolic order, the limit which humans may not trespass. Conversely, Badiou's Antigone subverts the state of the situation by displaying the rupture that lies at the heart of language, a rupture that is manifested by, but not reducible to, her evental statement. Hence Badiou succeeds in suspending truth from 


\section{Paragraph}

the subject-in-language: the rupture is not the truth, but opens up a gap for a truth to come.

Such is the logic of subtraction that underpins Badiou's thought: the truth is subtracted from the 'minimal difference' (the void in which the event is located) inherent in being-as-being, yet palpable in the symptomal point of the existing order of reality. Antigone, therefore, is the symptom, the external manifestation of this 'minimal difference'; she displays the 'minimal, albeit absolute, difference (...) between the place and what takes place in the place'. ${ }^{22}$ As we shall see, subtraction is the key that allows Badiou to untie the event from finitude and destruction, and to couple it instead with infinity and construction.

\section{From Purification to Subtraction: Badiou's Development}

Peter Hallward aptly summarizes the Badiousian project as 'the liberation of truth from the drive' $(B S T, 144)$ : fidelity to the truth is the 'opposite of repetition'. ${ }^{23}$ Against the drive, which seeks only its own destruction through obsessive repetition, Badiou posits the truthprocess as a gradual, endless investigation. Inseparable from creative, constructive thought, it is anathema to Lacan's non-thinking drive, which in Žižek's words reduces the subject to the utter stupidity of 'pre-symbolic substance in all its abhorrent vitality'. ${ }^{24}$ As Badiou says himself, "to be faithful to the event is to move within the situation that this event has supplemented, by thinking the situation "according to" the event' $(E, 41)$. Whereas the Lacanian subject is passive, inert and decaying, the Badiousian subject is active, interventionist and everevolving.

However, a more fruitful point of contrast is between Badiou's truthprocess and Lacan's psychoanalytic procedure itself, since they have a common foundation: that of thought. Whereas the (death-)drive is a mindless circling around the void, analysis is inseparable from a gradual, sequential thought-process. At this level, it is possible to see the derivations of Badiou's earliest work, Theory of the Subject, most notably the chapter entitled 'Lack and Destruction'. ${ }^{25}$ As we shall see, the necessity of 'subjective destitution' in analysis might account for Badiou's initial focus on destruction, which he later terms purification, in contrast to subtraction.

As Lacan's exploration of Antigone shows, the end of the psychoanalytic cure is the cathartic 'purification' of desire, the elimination process which involves shedding the layers of imaginary 
reality in order to reveal desire in its purest, real form (S VII, 303-5). For this to occur, the analyst, who throughout the process stood for the big Other, the (m)other, the illusion of the wholeness of a relation, must 'commit suicide', must be 'reduced to a mere surplus, a pure objet petit a' ${ }^{26}$ The destruction of illusory plenitude allows the subject to identify with his symptom, but results in subjective destitution, utter helplessness and solitude (Lacan, S VII, 304).

In this context, the role of the Lacanian analyst is analogous to that of the Badiousian state. By carrying out the 'count-as-One' of the situation, by giving it a symbolic structure, the state gives its members the illusion of totality; it is a barrier against the terrifying void of the situation. When the parallel between the two theories is extended when the Lacanian analysand is reconfigured as a Badiousian subject the analyst's 'suicide' becomes the violent (self-)destruction of the state. The subject of the destructive event experiences a similar exclusion to that of the helpless analysand: in Hallward's words, 'Badiou's subjects are always solitary, singular, always endangered' $(B S T, 124) .{ }^{27}$ Just as the Lacanian subject can only free himself completely from the prison of the symbolic order (in order to identify with his symptom, his truth) through death, for the early Badiousian subject, the only means of attaining the truth, of reaching the kernel of the real, is the destruction of the previous state of the situation.

This may, then, prove to be an explanation for Badiou's term 'destruction' in Theory of the Subject, which he would later proceed to criticize in The Century. In the latter, he insists on the choice between two forms of the 'passion for the real' that characterizes the twentieth century: destruction or subtraction $(T C, 54)$. He notes that he is 'particularly sensitive to the conflict between these two orientations since it has played a decisive role in [his] own philosophical trajectory' (54-5).

This trajectory arguably constitutes not only the liberation of the truth-process from the analytic process and the 'subjective destitution' it necessitates, but also the increasing awareness of the need to distinguish the truth from its semblance, Good from Evil. As Badiou admits, the real 'is never real enough not to be suspected of semblance'; hence the 'logic of purification (...) amounts to bringing about the nothing', since, ultimately, only dying 'escapes suspicion' (54). Yet as Badiou compellingly argues, purification is inextricably linked with simulation, fiction and theatricality. This is most chillingly illustrated by the Moscow show trials in the 1930s, which, under Stalin's motto that 'a party becomes stronger by purging itself', belong 


\section{Paragraph}

simultaneously to the realms of 'pure, real violence' and 'pure theatrical fiction' (51-3). Again, we are reminded of the analytic act, which, as its name suggests, is the mise-en-scène of the self-destruction of the analyst: it marries theatre and death, simulation and purification. Indeed, in psychoanalysis, just as in philosophy, nothing attests that the real is real 'but the system of fictions wherein it plays the role of the real' (52). Yet the relocation of the void-set from subject to being-as-being leads to the transformation of the analyst's staged suicide into the disastrous 'withering' of the state (in Lenin's terms). Hence it was necessary for Badiou to move away from the notion of destruction, and the theatricality with which it is associated, towards a thinking of the genuine event that emerges from the measured process of subtraction.

Kaufman's criticism of the fact that the truth-process is 'not that far removed from the very radical Evil Badiou attacks' (WF, 147) is quite justified, since Evil for Badiou is formally identical to Good. Yet it seems unfair to use this argument to defend Lacan against Badiou, since the simulation of the event is inextricably linked not only with the montages and masks that stem from the 'necessity of semblance' in the Lacanian imaginary order $(T C, 49)$, but also with the theatricality of the analytic act itself.

In this context, certain critiques of Badiousian destruction can be re-examined and qualified. Bosteels claims that the polemic between Lacan and Badiou, respectively, 'resides in the inescapable choice between lack and destruction'. ${ }^{28}$ Yet from the topological perspective adopted here, it is arguable that Lacanian psychoanalysis is inseparable from destruction due to the lack that inhabits the subject, whereas Badiousian philosophy manages to progress from destruction to subtraction as a different means of reaching the kernel of lack that resides in being-as-being. Žižek's rightful concern that, historically speaking, "subtraction is possible only after the fiasco of purification, as its repetition, in which the "passion of the Real" is sublated, freed of its (self-)destructive potential' (TA, 178), is thus reflected in the evolution of the theory itself: Badiou's unique subtractive philosophy is constructed on the existing foundations of Lacanian analysis.

\section{From Structure to Process: from Lacan to Badiou}

The need to move away from purification is best captured by Badiou himself: 
There exists a passion for the real that is obsessed with identity: to grasp real identity, to unmask its copies, to discredit fakes (...). This passion can only be fulfilled as destruction. Herein lies its strength - after all, many things deserve to be destroyed. But this is also its limit, because purification is a process doomed to incompletion, a figure of the bad infinite. $(T C, 56)$

One can certainly view Lacanian analysis as a means of unmasking and discrediting the fake identities, projections and identifications that constitute the imaginary order: the aim is to 'grasp real identity', to grasp the Freudian Thing that is 'in you more than you', albeit through the pure negativity of the subject's non-identity to himself. This concept is raised in Being and Event, where Badiou maintains that 'what still attaches Lacan (...) to the Cartesian epoch of science is the thought that the subject must be maintained in the pure void of its subtraction if one wishes to save the truth' $(B E, 432)$. In other words, what he owes to Descartes is the idea that there is such a thing as an authentic subject, a 'true' underlying identity. Badiou, conversely, by relocating the void in being-as-being, eliminates any such category: for him, there is no subject prior to the event; the subject is merely the exceptional coming-to-being of the event.

Two points from the above quotation will serve to highlight the transition from Lacanian analytic process to Badiousian truthprocedure. First, Badiou emphasizes the strength of the destructive process in the right context. In Lacan's system, it is both praiseworthy and necessary, since the false, self-deceptive identities of the imaginary order 'deserve to be destroyed'. Yet the strength of the analytic process becomes the weakness of the truth-process, especially in Theory of the Subject, in which 'destruction was [his] Beatrice', as he later avows $(T C, 55)$. Second, he links the limitations of destruction with the Hegelian 'bad infinite'. This ambiguous concept could also be referred to as the 'destructive infinite', since purification is a passion for the real that endlessly seeks - yet always fails - to gather and destroy any remnants of fakes pertaining to the imaginary or symbolic orders that hold back the real (or in Badiou's terms, of the old order which prevents the renewal of the state of the situation). The antithesis of the 'bad/destructive infinite' is thus the 'true/constructive infinite' that makes Badiou's later philosophy one of ceaseless real-ization and actual-ization through the constant subtraction of truth from the ontological domain of being-as-being.

One of Badiou's greatest achievements thus lies in his acknowledgement of the danger posed by the destructive mode within 


\section{Paragraph}

his own philosophy and in his consequent elaboration of truth as a process of subtraction and subjective constitution. Yet this is not to say that he moves away from the 'domain beyond the good'. On the contrary, he remains convinced that it is only through this domain that change can be thought. For Badiou, like Lacan, the space of the ethical can only lie in this limit, this extreme. The question, then, is how to subtract effective thought from a pre-symbolic domain of 'utter stupidity' (Žižek's terms), where any thought is still potential. Whereas the Lacanian subject - and consequently, the Lacanian thinker - remains obsessed with the old, compelled by a stagnant desire and repetitive drive that stem from a structural, originary void, the Badiousian subject — and thinker - enters the mindset of perpetual renewal. Lacan's 'never give way on your desire', the attachment to an unalterable structural lack, becomes 'always start again', the fidelity to an ever-evolving procedure of reconstitution. This is because, in his words, 'the new can only be thought as process' (CC, 253).

Appropriately, Badiou's philosophy of 'becoming' is itself everevolving. In the recent Logics of Worlds, a supplement to his founding Being and Event, Badiou elaborates his notion of the event to account for different degrees of change. Here, 'becoming' is subdivided three times, resulting in a crucial distinction between 'weak' and 'strong' singularities, thus transforming his theory of the event into a more nuanced theory of change. ${ }^{29}$ A 'weak' singularity, though not an event, has the potential to strengthen, and therefore eventually to produce an effective transformation. Though this elaboration on the one hand relies on prescriptions (notably the distinction between 'weak' and 'strong' singularities in terms of 'non-maximal' and 'maximal' consequences, respectively), Badiou's aim is to open up the question of the new in order to free up thought. His philosophy is faithful to his politics; both constitute a fidelity to continuous discontinuities, to the articulation of disarticulations.

This is perhaps why Žižek, the Lacanian critic par excellence, by attaching his thought to Lacan's psychoanalytic structures, ceaselessly folds the new back into the old, folds politics back into the overrestrictive corset of existing models. His over-fidelity to his master may paradoxically amount to a betrayal, since he fails to exploit Lacan's radical theory to its full potential. Badiou, in this respect, may be more faithful to Lacan than Žižek himself: by relocating and rearticulating the void, by reconstructing his models, and by transforming his structures into processes, Badiou's philosophy allows 
Lacan's psychoanalytic ontology to be remapped as a "new way in the desert' (TC, 58).

\section{NOTES}

1 Alain Badiou, Conditions, translated by Steven Corcoran (London and New York: Continuum, 2009), 137, 227.

2 Slavoj Žižek, The Ticklish Subject (London: Verso, 1999), 161; hereafter, all references to this edition will be made in the main text, using the abbreviation TS.

3 Eleanor Kaufman, 'Why the Family is Beautiful (Lacan against Badiou)', Diacritics 32:3-4 (2002), 135-51 (143); hereafter, WF.

4 Jacques Lacan, The Ethics of Psychoanalysis, The Seminar of Jacques Lacan: Book VII, edited by Jacques-Alain Miller, translated by Dennis Porter (London: Routledge, 2007), 268; hereafter, S VII.

5 Alain Badiou, Manifesto for Philosophy, edited and translated by Norman Madarasz (Albany: State University of New York Press, 1999), 104.

6 Alain Badiou, Being and Event, translated by Oliver Feltham (London and New York: Continuum, 2005), 522; hereafter, BE.

7 Alain Badiou, Ethics: An Essay on the Understanding of Evil, translated by Peter Hallward (London: Verso, 2001), 43; hereafter, E.

8 Alain Badiou, Theoretical Writings, edited and translated by Ray Brassier and Alberto Toscano (London and New York: Continuum, 2006), 39; hereafter, $T W$.

9 Peter Hallward, Badiou: A Subject to Truth (Minneapolis and London: University of Minnesota Press, 2003), 87-8; hereafter, BST.

10 Belonging refers to presentation, whilst inclusion refers to representation $(B E, 501)$. The event is by definition supernumerary, beyond the countas-One of the situation: though it belongs to the situation, it is not included within it.

11 Bruno Bosteels, 'Force of Non-Law: Alain Badiou's Theory of Justice', Cardozo Law Review 29:5 (2008), 1905-26 (1909).

12 'Good' and 'Evil' are capitalized when used in their Badiousian sense as singular truth-processes.

13 Alain Badiou, 'The Contemporary Figure of the Soldier in Politics and Poetry', UCLA, < http://www.lacan.com/badsold.htm > (2007), consulted 24 September 2010.

14 Alain Badiou, Saint Paul: the Foundation of Universalism, translated by Ray Brassier (Stanford: Stanford University Press, 2003), 109.

15 Jacques Lacan, The Four Fundamental Concepts of Psychoanalysis, Seminar XI, edited by Jacques-Alain Miller, translated by Alan Sheridan (London: Karnac, 2004), 263. 


\section{Paragraph}

16 Jacques Lacan, Seminar I: Freud's Papers on Technique, edited by Jacques-Alain Miller, translated by John Forrester (New York: Norton, 1988), 228.

17 In Being and Event, this speech act is termed evental nomination. However, the term is later revised in order to emphasize the fact that there is never any ontological remainder of the event: because the event leaves behind no name, it can only be implied, or suggested. Evental nomination therefore becomes evental statement $(T W, 148)$.

18 Peter Osborne, 'Neo-classic: Alain Badiou's Being and Event', Radical Philosophy 142 (2007), 25.

19 Bruno Bosteels, 'Can Change Be Thought? A dialogue with Alain Badiou', Alain Badiou: Philosophy and its Conditions, edited by Gabriel Riera (Albany: State University of New York Press, 2005), 237-61 (253); hereafter, CC.

20 Slavoj Žižek, 'From Purification to Subtraction: Badiou and the Real', in Think Again: Alain Badiou and the Future of Philosophy, edited by Peter Hallward (London and New York: Continuum, 2004), 177; hereafter, TA.

21 Jacques Lacan, The Seminar. Book III. The Psychoses, edited by Jacques-Alain Miller, translated by Russell Grigg (London: Routledge, 1993), 268.

22 Alain Badiou, The Century, translated by Alberto Toscano (Cambridge: Polity Press, 2007), 56.

23 Alain Badiou, 'Custos, quid noctis?', Critique 450 (1984), 851-63 (863).

24 Slavoj Žižek, The Žižek Reader, edited by Elizabeth Wright and Edmond Wright (Oxford: Blackwell, 1999), 19.

25 Alain Badiou, Theory of the Subject, translated by Bruno Bosteels (London and New York: Continuum, 2009).

26 Dylan Evans, An Introductory Dictionary of Lacanian Psychoanalysis (London: Routledge, 1996), 54.

27 It should be noted that the characteristics of the subject are not identical to those of the truth. While the subject of/to truth is solitary, the truth itself is neither solitary nor particular: it is a universal singularity.

28 Bruno Bosteels, 'Alain Badiou's Theory of the Subject: The Recommencement of Dialectical Materialism? (Part II)', PLI: The Warwick Journal of Philosophy 13 (2002), 173-208 (200).

29 See the very helpful graph in Alain Badiou, Logics of Worlds: Being and Event, 2, translated by Alberto Toscano (London and New York: Continuum, 2009), 374. 